\title{
O Professor Miguel Reale no Nordeste
}

A convite das secções da Ordem dos Advogados de Pernambuco, da Paraíba e do Sergipe, bem como dos Diretórios Acadêmicos das Faculdades de Direito do Recife e de Caruarú, visitou o Nordeste, na segunda quinzena de setembro, o Professor Miguel Reale, que estendeu a sua viagem à Fortaleza e a Salvador, afim de instalar na Capital cearense o Instituto de Filosofia e visitar a secção baiana da entidade a que preside.

A excursão cultural do mestre de Filosofia do Direito desta Faculdade alcançou a mais ampla repercussão, tendo sido êle saudado por figuras das mais representativas da Universidade e do Fôro do Nordeste, como os Professôres Pinto Ferreira, Lourival Vilanova, Paulo Bonavides, A. L. Machado Neto, José Silvério Leite Fontes e José Amado do Nascimento.

Como documentos ilustrativos do que foram as conferências e aulas proferidas pelo Professor Miguel Reale sôbre temas de Filosofia e de Filosofia do Direito publicamos, a seguir, três trabalhos dos eminentes juristas Pinto Ferreira, Augusto Duque e Mário Moacir Porto:

\section{Miguel Reale*}

\author{
Prof. Pinto Ferreira \\ Catedrático de Direito Constitucional e de \\ Sociologia na Universidade do Recife.
}

Quando um povo atinge a consciência do seu destino, começa a guiar a marcha da humanidade para o progresso

* Discurso de saudação ao prof. Miguel Reale, pronunciado no Tribunal de Justiça, a 21 de setembro de 1960, em nome da Ordem dos Advogados (Seçãa de Pernambuco), posteriormente reconstituído. 
e a consolidação do saber e do conhecimento. Através dessa tomada de consciência das suas possibilidades históricas, do reflexo e da admiração dêsse saber nas gerações sucessivas, uma nação pensa e vive, angaria o respeito do mundo e do pensamento universal. Nenhum povo se engrandece sem o cultivo da ciência e da filosofia, da arté e da literatura, do direito e da legalidade, do saber emancipado nas suas múltiplas manifestações.

É assim com encantamento que Pernambuco recebe uma das figuras impressionantes da história intelectual brasileira. A Ordem dos Advogados a acolhe com a fidalguia e o cavalheirismo que seu talento e sua personalidade granjearam por todo o país.

Esta Ordem dos Advogados, através da brilhante direção do seu atual presidente, o dr. José Neves, cujo dinamismo e operosidade avultam em realizações do mais surpreendente êxito no campo de suas atividades, está vivamente interessada em um programa cultural de envergadura. Colaborando com êle, visita-nos agora o prof. Miguel Reale, para trazer a sua preciosa contribuição, marcando um grande momento nesta festa da inteligência pernambucana.

Múltiplos são os traços em que se desdobra a figura do eminente intelectual brasileiro. Paulista de nascimento, dessa terra sagrada e consagrada por tantas epopéias liberais, cujo desenvolvimento econômico se assemelha às mais progressistas regiões européias, a que agrega uma vida espiritual cheia de densidade, com seus juristas, seus pensadores, seus poetas, seus estadistas, São Paulo ocupa um lugar de relêvo na paisagem nacional.

O dr. Miguel Reale é professor, por fôrça de concurso, da cadeira de Filosofia do Direito da Faculdade de Direito da Universidade de São Paulo. Inclusive o homem de ação, ex-Secretário da Justiça do seu Estado. ex-Reitor da sua Universidade, é um homem predestinado para as grandes realizaçôes. 
Jurista-filósofo, pensador social, escritor de nomeada, tratadista, advogado militante, em todos êsses domínios tem revelado o brilho inconfundivel do seu talento.

Como tratadista e escritor publicou trabalhos de projeção, entre êles se destacando as obras Fundamentos do Direito, Teoria do Direito e do Estado, Novos Horizontes do Direito e da História, Filosofia do Direito, esta última obra em vários volumes, e já traduzida para o estrangeiro, afora opúsculos, dissertações e teses.

A sua obra intelectual é densa, erudita e tem o privilégio da originalidade. E' o criador da teoria interpretativa da tri-dimensionalidade do direito, já bosquejada na Alemanha com a Dreiseitenslehre de Sauer, a que Reale deu contôrno original e próprio, em orientação que tem recebido críticas lisonjeiras dos Estados Unidos, Europa e diversos países latino-americanos. Jurista-filósofo é de certo a figura mais categorizada do pensamento brasileiro, neste setor.

A Miguel Reale cabe também o mérito de haver assinalado a contribuição de dois escritores nordestinos, Tobías Barreto e Sílvio Romero, ao campo da filosofia do direito e da filosofia em geral, contribuindo para o realce dos nomes dos mesmos. Tobias Barreto goza aliás de grande irradiação na Europa, homenageado recentemente na Alemanha, na Universidade de Hamburgo, pelo prof. Grossmann, por intermédio de uma placa com dizeres expressivos, e bem assim na União Soviética, onde o prof. J. Bazarian, colaborador científico do Instituto de $\mathrm{e}^{-}$Filosofia da Academia de Ciências da urss, o tem elogiado com artigos publicados em revistas russas. E' mais um laço que prende o mestre paulista ̀̀ nossa terra, revelando as suas afinidades espirituais e afetivas conosco.

Orador de renome nacional, o prof. Miguel Reale tem a medida, o calor, a segurança, a escôlha de expressão, do movimento, da gesticulação, para o fim exclusivo de enobrecer esta arte, fiel à sinceridade do seu estilo, à sua ternura pela verdade. 
Mas não é um homem submisso e contente. Não se prende no silêncio do gabinete. É um agitador de idéias, um estimulador de tendências, responsável pelo milagre de haver despertado o gôsto da inteligência brasileira para os estudos filosóficos. E' o criador do Instituto Brasileiro de Filosofia e da Revista Brasileira de Filosofia, desta já tendo publicado até hoje cêrca de 40 números.

Tal é a figura extraordinária que Pernambuco acolhe. Merece o respeito e a simpatia dos brasileiros, amantes do saber e da cultura. E' um homem de ação e de pensamento, que olha o futuro e não se perde na nostalgia embaladora do sonho e do passado. Michelet já havia dito: o sonho é o mal dos mundos e das almas que findam.

A cidade de Recife, um dos mais pitorescos refúgios que o mundo pode oferecer ao espírito de um pensador, apresenta-se hospitaleiro ao prof. Miguel Reale, que decerto se encontrará com a sua natureza exuberante, as suas praias e folhagens tropicais, as águas dos rios espelhados e dormentes, tocados pelo reflexo do sol, os verdejantes parques umbrosos e tranqüilos, a que se acrescenta ademais a simpatia dos seus amigos e admiradores.

Pernambuco assim, com as suas tradições históricas de saber e cultura, com as perspectivas do seu futuro, acolhe festivamente a uma das grandes figuras do pensamento brasileiro."

(De "O Jornal de Comércio", do Recife de 23-9-960)

Presença de Miguel Reale

\author{
Des. Augusto Duque \\ Desembargador do Tribunal de Justiça \\ de Pernambuco
}

Talvez seja uma simples impressão pessoal; mas, duvido muito que assim seja sòmente, tendo em vista o que observei em muitos. É o seguinte: considero a visita que o prof. Miguel Reale fêz, ùltimamente à Pernambuco, um 
acontecimento da maior repercussão para a nossa vida cultural, especialmente para os que se dedicam aos estudos jurídicos e de filosofia. E mesmo para os que, sendo juristas práticos, exercendo profissionalmente, atividades judiciárias em qualquer setor e tiveram a ventura do seu contacto intelectual, o episódio foi marcante. O prof. Miguel Reale que é hoje um dos luminares com que o Brasil pode apresentar-se no concêrto dos juristas de todo o mundo, teve a oportunidade de exercer, entre nós, durante alguns proveitosos dias, o seu esplêndido magistério. Não se reduz o professor paulista à proficiência dos seus lúcidos trabalhos em livros e ensaios, nos quais ressaltam-se aspectos maravilhosos de uma contribuição pessoal magnífica para a Ciência do Direito, para a Filosofia e para os estudos filosóficos em geral. Não fica o mesmo, sòmente, no seu gabinete, na sua cátedra, na sua banca de advogado onde, em qualquer dos ditos setôres de atividade, mereceria a admiração de todos. Porém, desdobra-se em profícua atuação intelectual, estimulando estudiosos e pesquisas, organizando centros de estudos sérios, de grande importância para a vida devotada às atividades culturais, num "tonus" de límpida grandeza espiritual, para conclamar os estudiosos para as fainas da inteligência.

Acontece que, além disso tudo, propositadamente, sem interêsses imediatos, sujeito às canseiras e aos percalços de quem, neste País, desajeitado, quer fazer alguma cousa sèriamente, o prof. Reale, diuturnamente, movimenta o seu integral magistério e espanca com a sua eloqüência, com a fôrça de sua inteligência e o vigor de sua cultura, lúcida e dinâmica, com o brilho de sua personalidade, o marasmático ambiente da maioria de nossos intelectuais, tendentes aos isolamentos, às atividades individualistas. Tão gostosos do sistema de quinaus intelectuais, das vaidades pelas gloríolas superficiais, das erudições de tópicos, como diria o admirável prof. Lourival Vilanova. E os convoca para os estudos sérios de filosofia e de direito, em um teor de atividade que signifique amadurecimento de nossas elites 
culturais para os altos estudos que poderão definir e assegurar, na história do pensamento humano, a presença do Brasil.

Independente do acêrto ou desacêrto de suas idéias de esplêndido filósofo do direito, da procedência de suas teses, cumpre pôr em relêvo êsse aspecto do meritório servîiço que o ilustre patrício está prestando à cultura brasileira, além do que já o consagrou como jurista e filósofo do direito, como magnífica vocação de mestre, admiràvelmente, realizada. Multiplica-se o prof. Reale, como aglutinador de inteligências, como catalisador de estudiosos, qué, ao seu contacto e sob a ação de seu atraente magistério, dispõem-se melhormente para as tarefas do espírito, para vibrar sob motivações mais amplas, mais profundas e mais significativas, para os belos lavôres da inteligência e da cultura.

Foi sob essa impressão que senti a presença de Miguel Reale no Recife. E espero que, em outras pessoas, tenha tido a mesma e igual repercussão.

("Jornal do Comércio", 5-X-960)

\title{
Miguel Reale na Paraíba
}

\author{
Prof. Mário Moacir Pôrto \\ Catedrático de Direito Civil, Desembargador \\ e Reitor da Universidade da Paraíba
}

Recebi do Sr. Presidente da Ordem dos Advogados, Seccẽa dêste Estado, a incumbência, por todos os títulos honrosa, de fazer a apresentação de $V$.Exa ${ }^{a}$, já às vésperas de sua chegada a nossa terra. O tempo exíguo, demasiadamente exíguo, que me restou para o desempenho de tâo relevante tarefa, longe de levar-me a uma fácil e prudente recusa, conduziu-me, ao contrário, a uma pronta e calorosa aceitação. E' que sou de V.Ex ${ }^{a}$., Professor Miguel Reale, discípulo antigo e admirador constante, e entre o demônio 
da vaidade de saudar o mestre e a temerária afoiteza de fazê-lo, venceu o imprudente aviso de que mais vale um gôsto do que seis vinténs.

Meus Senhores: a obra multifária, rica e poderosa de Miguel Reale não cabe nas estreitezas de uma apresentação e sobreexcede, evidentemente, os minguados recursos da minha palavra. Permito-me, portanto, sublinhar, nesta oportunidade, um único aspecto da sua atividade criadora, peculiaridade que dá à sua obra um destaque singular entre os juristas e filósofos do Brasil: a beleza do estilo, o apuro da forma, o poder, que é um dom de Deus, de extrair do cascalho das teorias mais áridas, as versões correntias do mais belo dizer. Para um jurista-filósofo dizer bem é talvez tão importante como dizer a verdade, pois o direito é essencialmente uma obra de arte. O necessário afinamento que deverá existir entre a disciplina jurídica e a realidade social, a coincidência que se impõe entre o "dado" dos chamados fatos normativos e o processo técnico de elaboração do positivismo jurídico, expressa, essencialmente, uma revelação estética, uma identificação entre o justo e o belo. A estética, assim, é quem fornece a medida do ordenamento legal, comportando-se como um metrônomo que acerta o passo da existência gregária pelo compasso da norma disciplinadora. A imitação da natureza ou a revelação da natureza através da intuição criadora é, em amplo sentido, o fim do direito e o objeto da arte. No plano do direito, o justo se constata através da satisfatória adequação das regras às realidades humanas, do mesmo modo que no território da estética o belo se revela na eleição da forma que forneça a medida do justo na interpretação da natureza. Razão tinha, pois, Platão quando proclamava que o belo é o justo, pois constituindo o direito um estilo normativo das atividades sociais, colima, em última análise, a escolha de um caminho numa encruzilhada ou contrapondo entre as dissonâncias dos conflitos humanos, o harmonioso andamento das diretrizes legais. A paz é, portanto, o preço da 
adequação, como a iniqüidade e a insubmisão são as conseqüências da incoincidência. Creio que não me colocaria ao arrepio das lições do mestre Reale se afirmasse que o justo, em si, é um problema da moral e não de política legislativa. Acontece, apenas, que reproduzir ou representar com a máxima fidelidade não é traduzir com a máxima perfeição. Se assim fôra, os trabalhos dos fotógrafos teriam liquidado a arte dos pintores. Mas não é difícil verificar que a pintura, apesar de não decalcar exatamente o modêlo, revela mais fielmente o objeto representado. É que os atributos essenciais do que se retrata, as qualidades preponderantes do que se fixa, é algo que se cria, não como subserviente projeção do que se visualizou, mas como pessoal representação do que se sentiu. A lei jurídica, de igual modo, não é perfeita quando exterioriza, fotogràficamente, o fato normativo. Para que se realize na plenitude da sua eficácia é de mister que das leis dos fatos informativos revele o interêsse preponderante, que acolha a tendência vitoriosa e, sem sobrepor-se aos dados inspiradores da conduta, apreenda e revele as diretivas centrais dêsse comportamento. Nos domínios da arte como no campo do direito, ver bem não é copiar o ostensivo mas revelar o oculto. Daí por que algo há de existîr além da norma, delimitando-lhe o raio de atuação, e algo de espiritual há de lastrear os fundamentos do sistema juridico, para que as imposições da sua disciplina não degradem o homem à condição de instrumento irracional da vontade do Estado. A lei não esgota o direito como a partitura não exaure a música. Interpretar é recriar, pois as notas musicais, como os textos da lei, são processos técnicos de expressão e não meios inextensíveis de exprimir. Há virtuoses do piano que são verdadeiros datilógrafos do teclado, como há intérpretes do direito que são subservientes repetidores dos textos. Infiéis à música e ao direito por excessiva fidelidade às notas e aos regulamentos, são instrumentistas para serem escutados e não intérpretes para serem entendidos. Há de se dizer, em análise apressada, 
que a obra admirável do professor Miguel Reale, no plano filosófico, não se valoriza por uma coerência isenta de reparos. Mas que é a verdade senão a escolha de um caminho numa encruzilhada, segundo o grau de compreensãó e honestidade de cada um? Pirandelo realçou, com extraordinária penetração, a natureza ambivalente do homem, advertindo que, por vêzes, a personalidade imposta pelas solicitações do meio social é mais real e poderosa do que a personalidade do indivíduo. Inquire Pirandelo: "Em que consiste a personalidade humana nas suas relações com a sociedade? Numa verdade profunda, que sòmente nós conhecemos ou na opinião que os outros fazem de nós? $\mathrm{E}$ a opinião dos outros não acabará por influir, de modo malévolo ou benévolo, naquela verdade profunda? E aquela verdade profunda é imutável ou se transforma incessantemente? Além disso, onde na vida termina a realidade e começa a ficção? Ainda mais: Se o espírito se submete a uma convicção esta não acabará por dominá-lo totalmente e mesmo por aniquilá-lo?

Já tive oportunidade de dizer e não fujo à satisfação de repetir que o homem só se afirma e constrói seguramente quando passa do mundo limitado do raciocinio para o mundo indemarcado da imaginação. Quem ousou afirmar, até hoje, que as telas de Ticiano ou os bronzes de Rodin são intrujices de diletantes? Mas que leis, sistemas ou exegeses, concebidas pelo homem para explicar ou disciplinar a vida e o mundo, resistiram, inabaláveis, ̀̀ revisão do tempo? A inteligência forceja por determinar as medidas do infinito e os seus artífices invariàvelmente se confundem na babel dos modêlos desencontrados. A imaginação, ao contrário, resume o universo, não em modelos que o expliquem, mas em representações que o manifestem. E não quero me furtar ao prazer de trazer para aqui uma admirável lição de Miguel Reale, filósofo "double" de artista: "Não há, em verdade, justiça sem homens justos, capazes de traduzir em atos de amor e de prudência 
o que lhes dita a consciência partícipe dos valores da comunidade; não há realização plena da justiça quando só a determinam frias proporções traçadas pelo intelecto, enquanto as fôrças afetivas permaneçam alheias ao seu processar-se, sem cuidado, sem simpatia, nem. comunhão espiritual".

Professor Miguel Reale: O auditório anseia por ouví-lo e não serei eu quem prorrogue o prazer da sua líção. Aqui vimos para ouvir e aprender. A palavra, pois, ao Mestre. 